\title{
Civil Service Reform in the Philippines: Building Strong
}

\section{Governance*}

\author{
Prijono Tjiptoherijanto \\ Universitas Indonesia, Depok, Indonesia
}

\begin{abstract}
The connection between administrative reform and civil society was an issue on the agenda of the New Public Management (NPM) in the 1960s and 1970s, while reinventing government movement has stimulated both interest in and criticism of the impact on civil society of public sector entrepreneurship. Modernizing the civil service starts by "bringing the citizens in". Therefore, a strong and sincere leadership in government's bureaucracy is needed. In the other words, building a strong and democratic government is a must.
\end{abstract}

Keywords: reinventing government, citizen involvement, strong leadership

\section{Introduction}

The Civil Service System in the Philippines is a product of its colonial history under Spain and the United States of America. The First Philippines Commission, otherwise known as the Schurman Commission, adopted and organized by America President William McKinley, laid down the foundation of the Philippines's Civil Service. This was established on January 20, 1899. The objective was to formulate the criteria for employment of Filipinos in the government. Therefore, as early as April 1899, the Schurman Commission guaranteed to the Filipino people an honest and effective civil service in which, to the fullest extent applicable, natives shall be employed.

\section{History of Reforms}

The Civil Service System in the Philippines was established by Act No. 5 on September 19, 1990 of the Second Philippine Commission entitled "An Act for the Establishment and Maintenance of an Efficient and Honest Civil Service in the Philippines Island". It established the framework for a merit based civil service system, mandating the appointment and promotion to government positions according to merit and through competitive examinations as far as possible.

The Bureau of Civil Service was established, then, on November 31, 1900, with the mandate that the greatest care should be taken in the selection of official for civil administration. To head the various executive and line agencies, the Philippine Commission preferred American civilians or military men who had been honorably discharged. All recruits, both American and Filipino, were to be men of the highest character and fitness who could conduct their duties unaffected by "partisan politics" (Report of the Philippine Commission, January 31, 1900, p. 121).

\footnotetext{
* Based on the field research conducted under the financial support from API-The Nippon Foundation (TNF), Tokyo, Japan, 2007-2008.

Prijono Tjiptoherijanto, Ph.D., Professor, Department of Economics, Universitas Indonesia, Depok, Indonesia.
} 
In 1916 the Civil Service Law was embodied in the new Administrative Code. The Bureau of Civil Service was, however, to continue under the control of an American director until Jose Gil was appointed in 1920 as the forst Filipino Director of Civil Service. American leadership, coupled with Filipino cooperation made possible good government service throughout the period of 1899-1920. The period 1913-1921 marked the rapid Filipinozation of Civil Service. In 1913, there were 2,623 Americans and 6,365 Filipinos in the government services. By 1921, there were only 614 Americans as against 13,240 Filipinos at the services.

On June 19, 1959, the new era for the civil service was ushered in with the approval by President Carlos P. Garcia of the Republic Act No. 2260 which set down the new Civil Service Law. It was one of the most progressive merit systems in the world at that time. Among many benefits, it provided career and employee development, employee suggestions and incentive awards, progressive performance rating and promotion plans, and opportunity for the establishment of complaints and grievances procedures.

Despite such efforts, many defects were still found in the civil service system. Delays in recruitment examination and placement of employees, inadequate discipline of civil service employee, the inability to attract persons of high caliber into the civil service, widespread use of the spoil system, and rampart graft and corruption were characteristics of the civil service until the decade of the 1970s.

By virtue of Presidential Decree No. 1, which was made part of the law of the land on September 24, 1972, President Ferdinand E. Marcos had implemented the Integrated Reorganization Plan (IRP) which promised the most extensive and wrenching effort at administrative reform in the country's history. The IRP provided for decentralizing and reducing the bureaucracy, and standardizing departmental organization. The IRP also sought to introduce structural changes and reforms to strengthen the merit system as well as professionalize the civil service system.

As far as the civil service itself was concerned, the IRP also provided the conversion of the single headed Civil Service Commission (CSC) into a three man body and the formation of the Career Executive Service (CES). Two dramatic purges undertaken in 1973 and 1975 through which thousands of government employees, including cabinet members, were red, delivered the message that the regime was not going to tolerate bad behavior. The bureaucracy under President Marcos became more subservient than at any other time in the Philippine history (Endriga, 2001, p. 216).

Under President Corazon Aquino, who was sworn in after the four day people power revolt of February 22-25, 1986, another wave of administrative reforms was introduced. Aside from restoring democratic institution and ratifying the new 1987's, Constitution of the Republic of the Philippines, guidelines for promoting public participation and private initiative in state and airs were established. Accountability institutions, such as CSC, Commission On Audit (COA), and Tanodbayan (an independent office of the ombudsman), which were established during the Marcos era, were given expanded powers under the new Constitution. Civil society organization became more visible in government decision making and program implementation. According to one observer, this was the most comprehensive articulation of bureaucracy for democracy (Carino, 1989, p. 12).

Taking advantage of its revolutionary character, the Aquino Government resorted to a purge of thousands of civil servants through the expedient of reorganization aiming to down size the bloated government bureaucracy. Although the said step was justified, paradoxically, the number of civil servants and political appointees, who did not enter through the traditional career system and many of them from the private sector, in 
the government, increased considerably. The proliferation of political appointees blurred the merit and career system of the civil service.

Civil service reform efforts were minimal during the presidential tenures of Fidel Ramos (1992-1998) and Joseph Estrada (1998-2001). President Ramos simply focused on giving life to the concept of New Public Management (NPM) with the end goal of reengineering the civil service. His hustle program was the "Philippines 2000" which was envisioned to make the country globally competitive by pursuing the thrusts of deregulation, market liberalization and privatization. The reengineering plan, however, remained just that with the Congress not lying down the legal framework for streamlining the bureaucracy.

Under the Estrada Administration, Executive Order No. 165 or "Directing the Formulation of an Institutional Strengthening and Streamlining Program for the Executive Branch" laid down the "Re-engineering the Bureaucracy for Better Governance Program" which eventually prompted the creation of the Presidential Committee on Effective Governance (PCEG). The PCEG was also tasked with creating an Integrated Administrative Reform Plan. President Estrada's term however, was plagued with charges of corruption and incompetence, and the reengineering initiatives had the same fate as that of the Ramos Administration's plan. The so-called "Edsa Dos" or "another people power", mobilization un-seat President Estrada from January 16 to 20, 2001, abruptly ending Estrada's 2.5 years rule and Vice President Gloria Macapagal Arroyo (GMA), was immediately sworn in as President of the Republic of the Philippines.

Upon her ascendance to office, President Gloria Macapagal Arroyo (2001-2010) continued the initiatives to streamline the bureaucracy, but as yet no overall agenda for reform in the bureaucracy. In the Medium Term Philippine Development Plan (MTPDP) 2001-2004, the administration had adopted the "Reengineering the Bureaucracy for Better Governance Program" inherited from the Estrada's administration. The PCEG was likewise reactivated as the ad-hoc body that shall be the focal point of administrative reforms in the civil service. In October 4, 2004, the Department of Budget and Management (DBM) and the CSC pursued the Rationalization Program as mandated in the executive order from the Presidents.

The Philippine bureaucracy is generally weak and not fully designed to cope with the needs of development or successfully undertake reform efforts. For nearly half a century, the Philippines was caught in an endless cycles of reform exercises that hardly produced tangible and lasting results. In fact, its lack of administrative capacity made institutionalizing such needed reforms extremely difficult. As a survey conducted in February 1992 by the Social Weather Stations (SWS), a reputable poling organization in the Philippines showed that high government officials were perceived as not suited to their positions (Dayag \& Lopez, 1993). The same survey also had the findings of the civil service characteristics as summarized in the following Table 1 below.

Considering the facts described in Table 1, the major challenge is, therefore, to transform the bureaucracy into well-performing institution that satisfies public demands and response to the challenges of globalization and national development objectives. In this regards, the role of civil society as an alternative frontline service delivery mechanism, especially at the local level, shall be encouraged.

\section{Toward Administrative Reform}

The connection between administrative reform and civil society was an issue on the agenda of the New Public Management (NPM) in the 1960s and 1970s, when social equity and popular empowerment were raised by critics of government management (Frederickson, 1996). More recently the reinventing government 
movement has stimulated both interest in and criticism of the impact on civil society of public sector entrepreneurship. Modernizing the civil service starts by bringing the citizens in. It calls upon public servants to treat citizens well as they extend service.

Table 1

Attributes of the Philippine Civil Service, February 1992

\begin{tabular}{lll}
\hline No. & Attribute & Percentage of respondents view \\
\hline I. & Negative & 40 \\
\hline & I.1. Corrupt & 25 \\
I.2. Arrogant & 20 \\
I.3. Alcoholic & 19 \\
I.4. Always out of the office & 16 \\
I.5. Indifferent & 16 \\
\hline II. $\quad$ Lacks Zest & \\
\hline & Positive & 27 \\
& II.1. Efficient & 25 \\
& II.2. Courteous & 21 \\
\hline
\end{tabular}

Source: Dayag \& Lopez, 1993, Table 1, p. 1.

In the Philippines the landmark of such administrative reforms was the introduction of the Integrated Reorganization Plan (IRP) in 1972. The IRP, which was the result of a two year effort of the Reorganization Commission, a few trusted technocrats of President Ferdinand Marcos, promised the most extensive and wrenching effort at administrative reform in the country's history. The IRP provided for decentralizing and reducing the bureaucracy, and standardizing departmental organization.

The IRP also sought to introduce structural changes and reforms to strengthen the merit system as well as professionalize the civil service system ${ }^{1}$. However, the stakeholders, who were to be affected by the program, were not involved. For that reason, a sense of ownership of and popular support for the program could never have been achieved, especially when implementation faltered because erring political leaders and their cohorts increasingly undermined the system and violated set standards and procedures.

To restore government integrity and public confidence reorganization reform were introduced by President Corazon Aquino, basically with the creation of Presidential Commission on Public Ethics and Accountability and the Presidential Commission on Good Governance (PCGG). Civil Service Organizations (CSOs) became more active in participating in decision making and program implementation of the government. To down size the bloated government, one of the step undertaken during the Aquino administration was the removal of thousand of civil servants from their positions. Although the said step was justified, ironically, the number of civil servants and political appointees in the government increased, thus blurring the principles of merit and fitness of the civil service. Moreover public agencies and offices grew which caused the extended and fragmented government structure (ADB, 2005).

\footnotetext{
${ }^{1}$ For completed information on the IRP, see: Commission on Reorganization (1972), "Integrated and Reorganization", Manila, Philippines, March, 1972.
} 
Table 2

Required Shift in Paradigm

\begin{tabular}{|c|c|c|c|}
\hline & \multirow[t]{2}{*}{ Area of concern } & \multicolumn{2}{|l|}{ Shift paradigm } \\
\hline & & From & To \\
\hline 1. & Role of civil servants & Follower/implementator & $\begin{array}{l}\text { Source of expertise and } \\
\text { institutional memory }\end{array}$ \\
\hline 2. & $\begin{array}{l}\text { Recruitment of civil } \\
\text { servants }\end{array}$ & Aptitudes/skills & $\begin{array}{l}\text { Service value orientation and } \\
\text { integrity of character }\end{array}$ \\
\hline 3. & $\begin{array}{l}\text { Role of 3rd level } \\
\text { officials }\end{array}$ & Administration/managers & Visionaries/technocrats/experts \\
\hline 4. & Appointment and & Bias for managerial skills & $\begin{array}{l}\text { Competitive process/insulated } \\
\text { from politics }\end{array}$ \\
\hline & promotions to 3 rd level & & $\begin{array}{l}\text { Major consideration are: character, } \\
\text { competence, and potentials } \\
\text { Competence encompass managerial } \\
\text { and technical skills }\end{array}$ \\
\hline 5. & Management style & $\begin{array}{l}\text { Subservience to hierarchy } \\
\text { /authoritarian }\end{array}$ & Participatory/consultative \\
\hline 6. & $\begin{array}{l}\text { Operating perspective } \\
\text { of the government }\end{array}$ & Regulation & Assistance and service \\
\hline 7. & $\begin{array}{l}\text { Civil service } \\
\text { relationship with other } \\
\text { branches of government }\end{array}$ & $\begin{array}{l}\text { Being an adjunct of other } \\
\text { branches }\end{array}$ & $\begin{array}{l}\text { Autonomy from the will of } \\
\text { political regime }\end{array}$ \\
\hline
\end{tabular}

Source: Sto Thomas \& Mangahas (2002), Table 7, p. 14.

While reorganization efforts were minimal during the tenures of Ramos and Estrada Administrations, President Gloria Macapagal Arroyo (GMA) continued the initiatives to streamline the bureaucracy. In the Medium Term Philippine Development Plan (MTPDP) 1999-2004², the present administration had adopted the "Reengineering the Bureaucracy for Better Governance Program" inherited from the Estrada's Administration. The Presidential Committee on Effective Governance (PCEG) which created by President Joseph Estrada was likewise reactivated upon the President's assumption to office. It serves as the ad-hoc body that shall be the focal point of administrative reforms in the Civil Service. In October 4, 2004, the Department of Budget and Management (DBM) and the Civil Service Commission (CSC) pursued the Rationalization Program as mandated in the Executive Order (EO) No. 366. The objective of the Program is to conduct a strategic review of all department agencies of the Executive Branch on their operations and organizations for purpose of focusing government efforts on its vital functions and channeling government resources to these care public functions, and improving the efficiency of government services within affordable levels, and in the most accountable manner.

In accordance with MTPDP, the Civil Service Commission (CSC) also formulated a comprehensive and strategic plan to address gaps and weakness in the bureaucracy ${ }^{3}$. The CSC Plan calls for a paradigm shift in the

\footnotetext{
2 More elaborated information, see: National Economic and Development Authority (1999), Medium Term Philippine Development Plan 1999-2004, NEDA, Manila, Philippines, 1999.

3 See: Civil Service Commission. Undated. The Civil Service: Building Its Own Integrity, The Civil Service Commission Strategic Plan For 2002-2004, CSC, Manila, Philippines.
} 
government mindset and attitude in terms of role, function, structure, and process, as summarizes in the following Table 2 .

In keeping with total client satisfaction, the CSC also introduced the so called "Mamamayan Muna, Hindi Mamaya Na" Program or MMHM Program (Leon, 1999). The MMHM Program which translates literally in English as "Citizen Now, Not Later" is essentially a client feedback mechanism meant to improve the delivery of public service. Launched in 1994, it is designed purposely to minimize if not totally eradicate discourtesy, arrogance, and inefficiency in the public service. In essence, the program operates this way: A client who feels dissatisfied with the service of government agency can bring a complaint to the attention of the CSC, which in turn, mediates between the client and the agency towards effective resolution of the complaint. Conversely, a client can report a satisfactory service, which when duly verified by the CSC, can reward the employee who rendered that satisfactory service with a citation or incentive.

\section{Concluding Remarks}

The Philippine Civil Service System faces tougher challenges, given the premiere of globalization, the growing trend toward greater civil society and private sector participation in the management of state affiairs, and the paradigm shift in the government's role from command and control to facilitation and flexibility. Increasingly, stakeholders are realizing and accepting that the government cannot fulfill its mandate effectively if it operates in isolation.

For nearly half a century, the Philippines were caught in endless cycle of administration reform exercises that hardly procedure tangible and lasting result. Lack of acceptance of and commitment to the need for reform by political authorities and various entities, as well as lack of stakeholder appreciation over long and continuous processes of administrative reform, were among the reasons behind the lack of success. Another stumbling block is the practice of corruption and cronyism in the Philippines, even before its independence. Therefore, a strong and sincere leadership is needed. In the other words, building a strong and democratic governance is a must.

\section{References}

Asian Development Bank (ADB). (2005). ADB country governance assessment: Philippnes. Manila, Philippines.

Corino, L. L. V. (1989). A dominated bureaucracy: An analysis of the foundation of, and reaction to state policies on the philppines civil service. Occasional Paper No. 89-4, College of Public Administration, University of the Philippines, Diliman, QC.

Dayag, C. C., \& Lopez, M. G. S. (1993). Are Philippines Ready for Decentralization. Survey updates on civil servants and the civil service. In Social Weather Bulletin 93, 14(July), 1-11. Quezon City: Social Weather Station Press.

Endriga, J. N. (2001). Civil service system in Asia, chapter the national civil service system of the Philippines. United Kingdom: Edward Elgar Publishing Ltd.

Frederickson, G. H. (1996). Comparing the reinventing government movement with the new public ad-ministration. Public Administration Review, 56(3), 263-270.

Leon, G de., \& Alma, C. (1999). Innovations and Best Practices in the Philippines Civil Service Commission. In The World Conference in Governance, 2 June 1999, EDSA Shangrilla Plaza Hotel, Manila, Philippines.

Report of the Philippine Commission. (January 31, 1900). Washington, DC: GPO, 1902-1916.

Sto Tomas, P. A., \& Mangohas, J. V. (2002). Public administration and governance: How do they affect government efficiency and effectiveness? In International Conference on Public Administration Plus Governance, 21-23 October 2002. 